\title{
Trace element concentrations by Laser Ablation ICP-MS in subcalcic garnets from Saskatchewan and Somerset Island, Canada
}

Jacob, D.E. ${ }^{1}$, Kjarsgaard, B. ${ }^{2}$, and Horn, I. ${ }^{3}$

1. Mineralogisch-Petrologisches Institut, University Göttingen, Goldschmidtsr.1, D-37077 Göttingen, FRG

2. Geological Survey of Canada, Ottawa, 601 Booth St., Ottawa, Ontario, Canada

3. Dept. Earth Sciences, Memorial University of Newfoundland, St. John's, Newfoundland, A1B 3X5, Canada; present address: Dept. Earth Planet. Sci., Harvard Univ., 20 Oxford Street, Cambridge, MA 02138, USA

Although subcalcic garnets have experienced substantial attention as diamond indicator minerals during the past 30 years, their genesis and recently also their age are still under debate. Jacob et al. (1998) studied the radiogenic isotope systematics of single subcalcic garnet grains from Yakutian kimberlites and proposed that subcalcic garnets are formed by metasomatism of spinel harzburgites in the diamond stability field. This reaction involved a carbon-bearing fluid or melt and produced subcalcic garnets and olivine at the expense of spinel, orthopyroxene and clinopyroxene (if present). Jacob et al. (1998) further proposed that this process occurred episodically during the craton's history and that kimberlites randomly sample different populations of garnets of different ages which are not cogenetic, therefore shrouding their genetic processes.

To test these hypotheses and to further constrain the proposed reaction, we have analysed trace elements in subcalcic garnet grains from Canadian kimberlite pipes by Laser-Ablation ICP-MS (LAM).

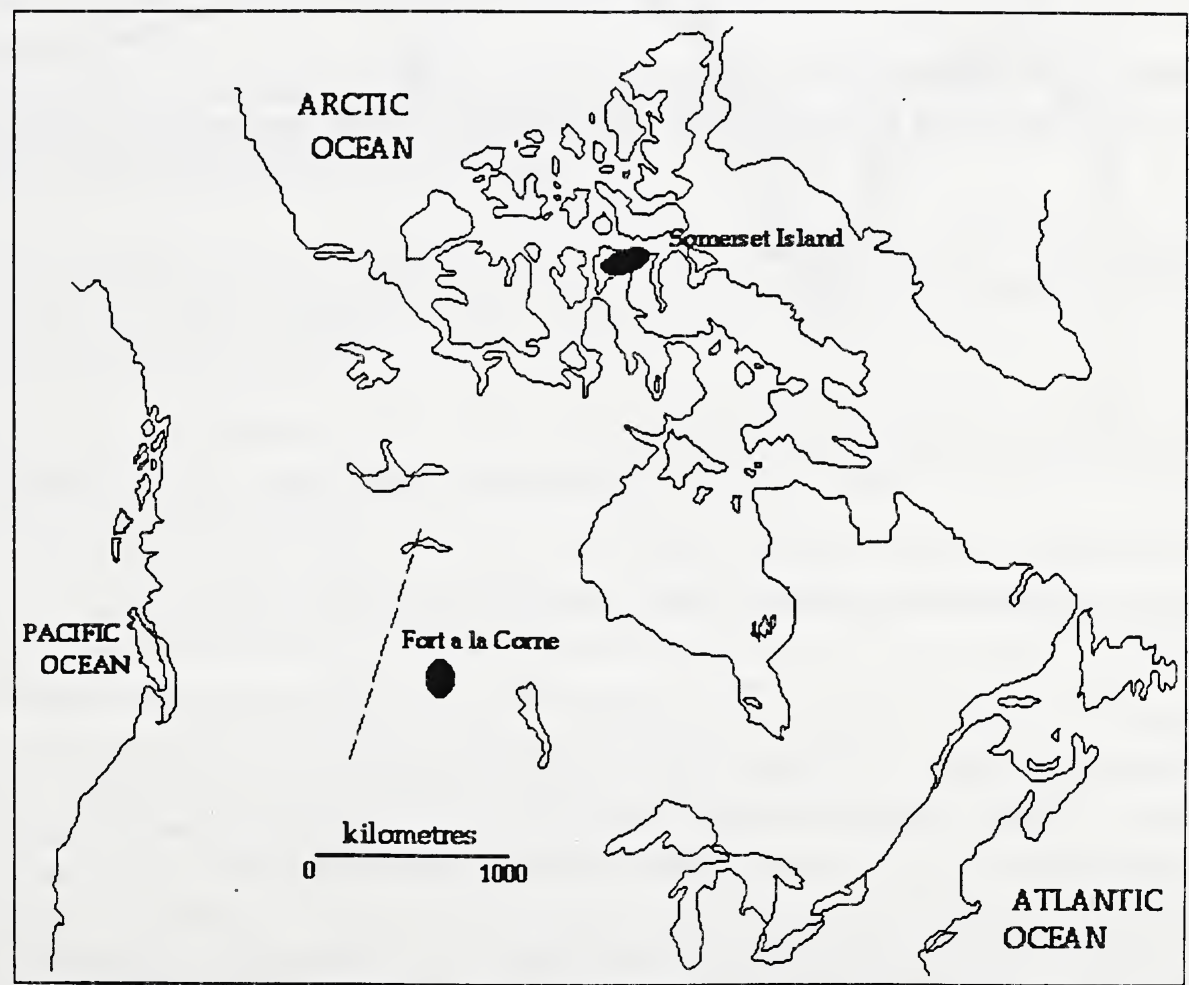

Fig. 1 Map of Canada with locations of studied subcalcic garnets 
Sub-calcic garnets used in this study are from two kimberlites, one from the Somerset Island field, NWT and the other from the Fort à la Corne field, Saskatchewan (Fig. 1).

Peridotite xenoliths are common in the outcropping K13 (or Nanorluk) hypabyssal kimberlite phase of the Batty Bay root zone complex at Somerset Island (Kjarsgaard and Peterson, 1992). Samples $\mathrm{K} 13-\mathrm{B} 1$ and $\mathrm{K} 13-58$ are sub-calcic garnets from harzburgite xenoliths. On a $\mathrm{CaO}-\mathrm{Cr}_{2} \mathrm{O}_{3}$ bivariate plot, both garnets lie at lower calcium contents than the Somerset Island lherzolite garnet field (based on combined xenolith and concentrate studies), and fall into the G10 field using the $85 \%$ line of Gurney (1984).

The two sub-calcic garnets from crater facies kimberlite \#120 in the Fort à la Corne field, Saskatchewan (samples FAC25 and FAC31) were derived from heavy mineral concentrates. Both garnet samples lie at lower calcium contents than the Fort a la Corne lherzolite garnet field (based on combined xenolith and concentrate studies: Kjarsgaard, unpublished data), and fall into the G10 field using the $85 \%$ line of Gurney (1984).

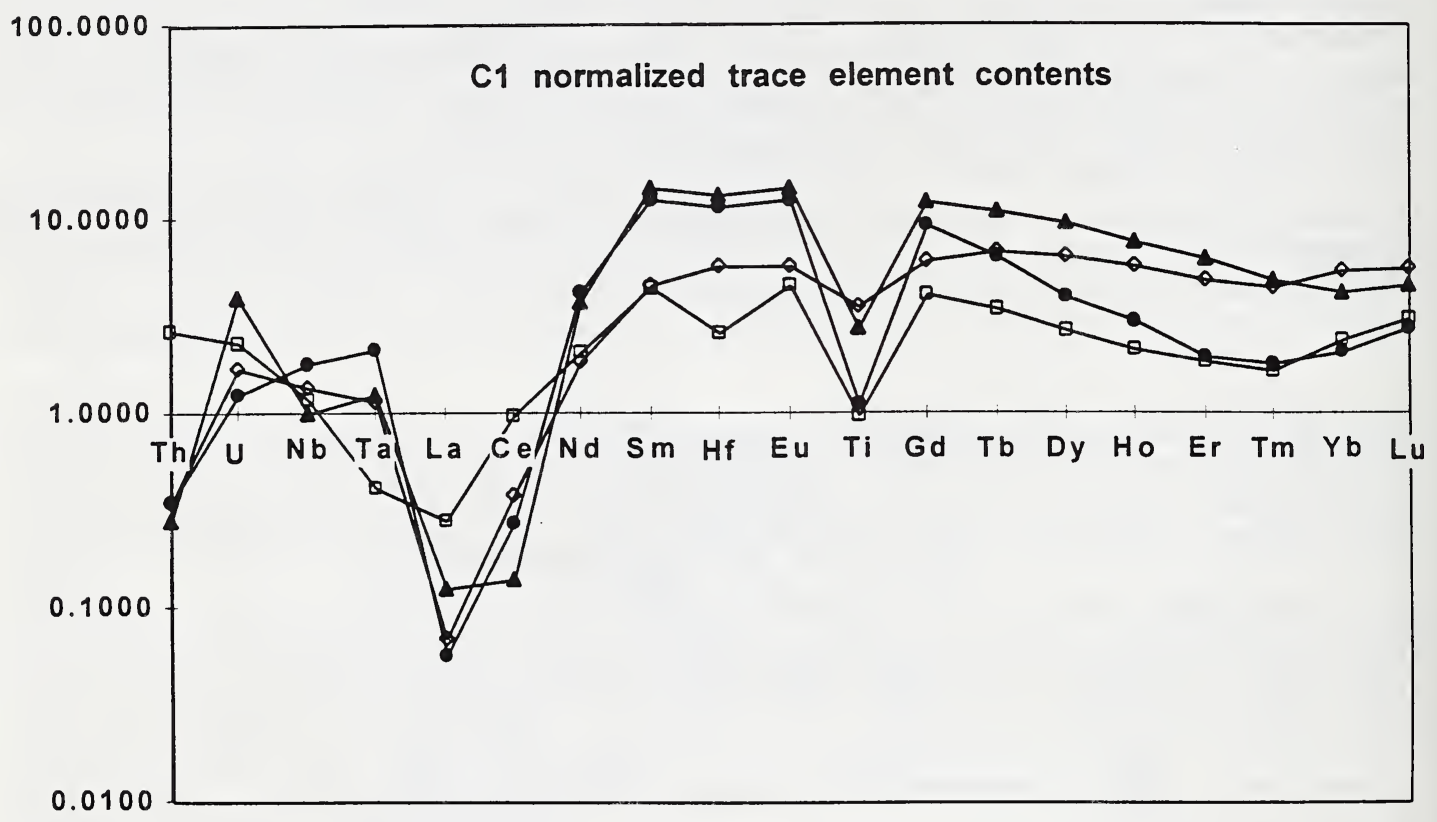

Fig.2 Spidergram of trace element contents of subcalcic garnets from Fort à la Corne (open symbols) and Saskatchewan (solid symbols) normalized to chondritic values.

Figure 2 shows the chondrite-normalized spidergrams of the studied garnets. Although the shape of the patterns are similar, absolute concentrations are very variable, even between grains from one pipe. This is typical for subcalcic garnets and similar to findings by e.g. Shimizu et al. (1997) and Stachel et al. (1998). Compared to a garnet composition from a high temperature sheared lherzolite from Jagersfontein (J4; Fig.3) the Canadian subcalcic garnets show depletion in heavy rare earth elements (HREE) as well as in Ce and La (not shown). Ten subcalcic garnets in harzburgites from Roberts Victor (Stachel et al., 1998) are more depleted in Ti, but more enriched in light rare earth elements (LREE). Thirty diamond inclusions from Yakutian kimberlites (Shimizu et al., 1997) show a large range of trace element contents; compared to our small dataset, the majority of the garnets of Shimizu et al. (1997) is a little more depeleted in HREE. 


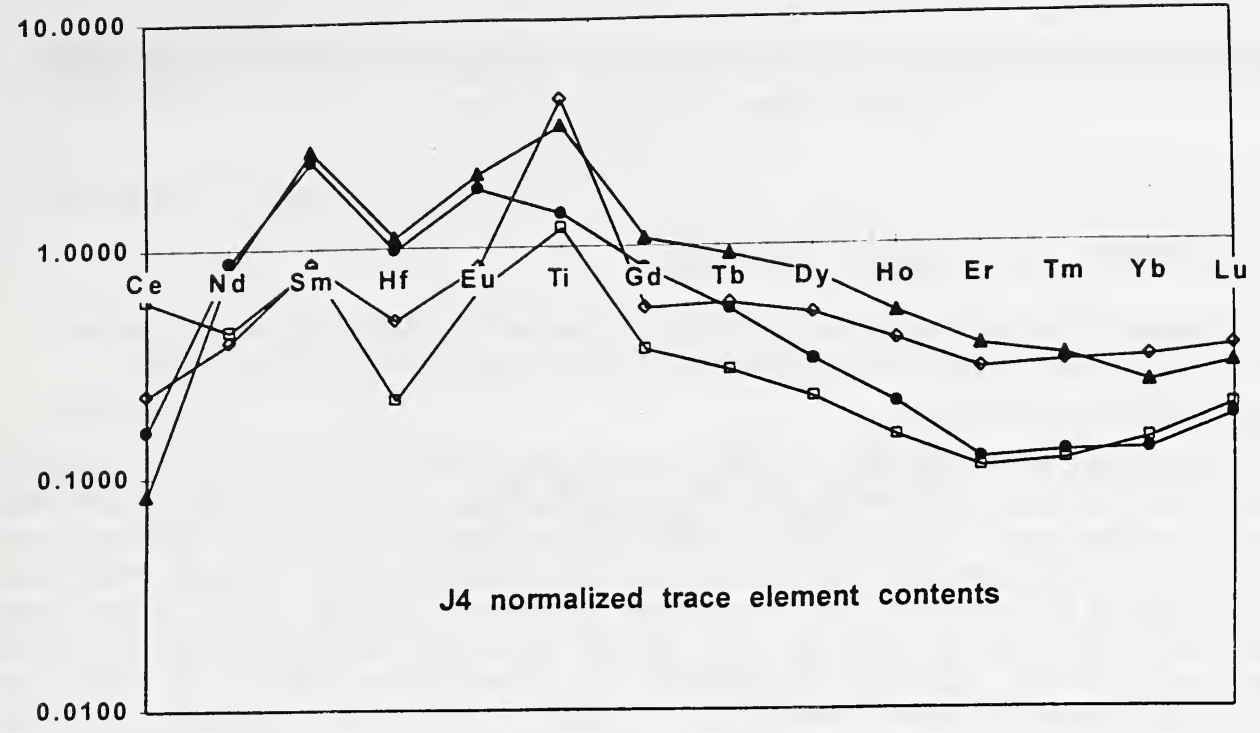

Fig.3 Trace element contents of subcalcic garnets from Fort à la Corne (open symbols) and Saskatchewan (solid symbols) normalized to J4 lherzolitic garnet (data from Jagoutz and Spettel in Wolff-Boenisch 1994)

\section{References}

Gurney, J.J. 1984, A correlation between garnets and diamonds. in Kimberlite Occurrence and Origin, A basis for conceptual Models in Exploration: J.E. Glover and P.G. Harris (ed) University of Western Australia Publication 8, p. 143-166.

Jacob, D.E., Jagoutz, E. and Sobolev, N.V., 1998, Neodymium and strontium isotopic measurements on single subcalcic garnet grains from Yakutian kimberlites: N. Jahrbuch Mineralogie Special Issue, in press.

Kjarsgaard, B.A. and Peterson, T.D. 1992, Kimberlite-derived ultramafic xenoliths from the diamond stability field: a new Cretaceous geotherm for Somerset Island, Northwest Territories: in Current Research 1992-B, Geological Survey of Canada, p. 1-6.

Shimizu, N., Sobolev, N.V. and Yefimova, E.S., 1997, Chemical heterogeneities of inclusion garnets and juvenile character of peridotitic diamonds from Siberia: Russ. Geology and Geophysics, 38, p. 356-372.

Stachel, T., Viljoen, K.S., Harris, J.W. and Brey, G.P., 1998, Trace element concentrations in garnets from diamondiferous peridotite nodules from the Roberts Victor kimberlite - a comparison with garnet inclusions in diamond: Earth Planet. Sci. Lett., in press.

Wolff-Boenisch, B., 1994, Aufbau der Analytik zur Messung der Osmium-Isotopie sowie die Strontium-, Neodym- und Osmium-Systematik eines Hoch-Temperatur-Granat-Lherzoliths (J4) von Jagersfontein (Südafrika): Mainz (Germany), Dipl. Thesis. 